\title{
Elicitation effect on cell biomass and production of alkaloids in cell suspension culture of the tropical tree Eurycoma longifolia
}

\author{
Chan Lai Keng ${ }^{1}$, Ang Sze Wei ${ }^{2}$ and Arvind Bhatt ${ }^{3}$ \\ $1,2,3$ School of Biological Sciences, Universiti Sains Malaysia, 11800 Penang, Malaysia \\ 3arvin_bhatt@rediffmail.com
}

Received 1-III-2010 Corrected 20-IV-2010 Accepted 28-IV-2010

\begin{abstract}
The present study tests the effect of different elicitor on cell biomass and alkaloid production in Eurycoma longifolia cells. The cell suspension cultures were prepared by inoculating $0,5 \mathrm{~g} \mathrm{FW}$ (fresh weight) of cells obtained from first batch of suspension cultures prepared from callus in liquid MSBs medium. Different concentration of chitosan, $\mathrm{NaH}_{2} \mathrm{PO}_{4}, \mathrm{Na}_{2} \mathrm{CO}_{3}$ and polyvinylpyrrolidone (PVP) were added as elicitor to optimize cell biomass and alkaloid production. MSBs medium supplemented with $100 \mathrm{mg} / \mathrm{L}$ chitosan induced significant increment in the cell biomass while higher amount of chitosan $(150 \mathrm{mg} / \mathrm{L})$ induced the highest production of 9-hydroxycanthin-6-one $(0,44 \%)$ but not 9-methoxycanthin-6-one. The addition of $2 \mathrm{mg} / \mathrm{L}$ and $20 \mathrm{mg} / \mathrm{L} \mathrm{NaH}_{2} \mathrm{PO}_{4}$ induced the highest increment in cell biomass and alkaloid production respectively. However, addition of different concentration $\mathrm{Na}_{2} \mathrm{CO}_{3}$ and polyvinylpyrrolidone showed inhibitory effect on cell growth with no significantly increased in alkaloid production.
\end{abstract}

\section{KEY WORDS}

Cell suspension culture, Eurycoma longifolia, medicinal plant, secondary metabolites.

\section{RESUMEN}

Analizamos el efecto de varios "reveladores" en la biomasa celular y la producción de alcaloides en células del árbol asiático Eurycoma longifolia. Las suspensiones celulares fueron preparadas por inoculación $0,5 \mathrm{~g} \mathrm{FW}$ (peso fresco) de células extraídas de suspensiones celulares de primer procesamiento preparadas de callos celulares en medio líquido MSBs. Agregamos quitosan, $\mathrm{NaH}_{2} \mathrm{PO}_{4}, \mathrm{Na}_{2} \mathrm{CO}_{3}$ y polivinilpirrolidona (PVP) como reveladores para aumentar la biomasa celular y la producción de alcaloides. El medio MSBs con $100 \mathrm{mg} / \mathrm{L}$ chitosan induce un incremento significativo en la biomasa celular mientras que un aumento de quitosan $(150 \mathrm{mg} / \mathrm{L})$ induce una alta producción de 9-hidroxicanthina6-uno $(0,44 \%)$, pero no de 9-metoxicanthina-6-uno. La adición de $2 \mathrm{mg} / \mathrm{L}$ y $20 \mathrm{mg} / \mathrm{L} \mathrm{NaH} \mathrm{PO}_{4}$ aumenta la biomasa celular y la producción de alcaloides respectivamente. Sin embargo, la adición de $\mathrm{Na}_{2} \mathrm{CO}_{3}$ y polivinilpirrolidona muestran un efecto inhibitorio en el crecimiento celular y en la producción de alcaloides no hay un aumento significativo.

PALABRAS CLAVE

Suspensión celular, Eurycoma longifolia, planta medicinal, metabolitos secundarios.
Eurycoma longifolia Jack is an evergreen tree growing up to $10-15 \mathrm{~m}$ in height. It is widely distributed in South East Asian countries such as Malaysia, India, China, Indonesia, Philippines and Thailand. It is commonly found in understory of the lowland forests up to 500m above sea level (Goh et al. 1995). It is commonly known as Tongkat Ali in Malaysia, Singapore and Brunei.

E. longifolia is an important medicinal plant and every parts of the plants are utilized for medicinal puroposes (Jiwajinda et al. 2002, Osman et al. 2003). Leaves are used to treat diarrhea, fever, glandular swelling, bleeding, dropsy, persistent cough, hypertension, relief of pain in the bones and malaria. The pulverized bark is used by aboriginal folks to treat wounds, ulcers, syphilitic sores and headache. The pulverized root or the root extract is used as tonic for women to recover after child birth (Bedir et al. 2003). In Vietnam, the bark is used to reduce difficulties of swallowing food and to treat lumbago. Vietnemese also uses the plant extract to treat cancer (Ueda et al. 2002). In Cambodia, the root is used as an antidotal remedy and to treat icterus, the yellowish discoloration of the whites of the eyes, skin, and mucous membranes caused by deposition of bile salts in these tissues (Perry \& Metzger 1980).

The roots of E. longifolia were found to contain quassinoids and some alkaloids that had been proven to possess 
anti-malarial, anti-ulcer, antipyretic, cytotoxic, antiproliferative, aphrodisiac properties and plant growth inhibition activities (Morita et al. 1990, Zhari et al. 1999, Kuo et al. 2003, Nurhanan et al. 2005, Chan et al. 2005, Tee \& Azimzhtol 2005, Hout et al. 2006).

E. longifolia is diocious in nature and produces fruits only once a year (August-September). Approximately 200-300 fruits are produced by a tree in one season. Moreover, the plant takes a long time to reach maturity and usually the whole plant is uprooted for medicinal preparation. This has caused an adverse effect on the natural population of $E$. Iongifolia. Production of bioactive compounds via cell suspension culture technology can be used as an alternative to solve this problem. The present study was hence carried out to evaluate the elicitation effect on E. longifolia cell biomass and the production of alkaloids, 9-hydroxycanthin-6-one and 9-methoxycanthin-6-one. At the same time to identify a suitable elicitor that could increase the cell biomass and the content of both of the alkaloids.

\section{MATERIALS AND METHODS}

Callus culture of Eu9 line of E. longifolia that produced stable and moderate amount of alkaloids and maintained at Plant Tissue and Cell Culture Laboratory, School of Biological Sciences, Universiti Sains Malaysia, Penang, Malaysia for three years was used in the present study. The cell suspension cultures was prepared by inoculating $0,5 \mathrm{~g}$ homogenous Eu9 callus in $25 \mathrm{ml}$ of MSBs, a modified MS medium formulated by Lufthi (2004). The pH of the medium was adjusted to 5,75 prior to autoclave at $121^{\circ} \mathrm{C}$ and $1,05 \mathrm{~kg} / \mathrm{cm}^{3}$ for 13 minutes with Elite Sterilizer (EAC$400^{\circ} \mathrm{C}$ ). The cultures were maintained at $22^{\circ} \mathrm{C} \pm 2{ }^{\circ} \mathrm{C}$ and exposed to 24 hours photoperiod with light intensity of $32,5 \mu \mathrm{E} \mathrm{m}^{-2} \mathrm{~s}^{-1}$. The culture were placed on an orbital shaker and agitated at $120 \mathrm{rpm}$ for 13 days. The subcultures were performed at 13-day intervals with $0,5 \mathrm{~g}$ fresh cell as inoculum.

Different concentration of chitosan, $\mathrm{NaH}_{2} \mathrm{PO}_{4}, \mathrm{Na}_{2} \mathrm{CO}_{3}$ and polyvinylpyrrolidone were added as elicitors into MSBs, the cell proliferation medium, a day before havesting the cell. The experiment was carried out using randomized complete block design. The cell FW was determined on the $13^{\text {th }}$ day of culture. Thereafter the cells were air dried to constant weight for determination of cell dried weight (DW).

About $0,25 \mathrm{~g}$ of dried cell powder was weighed and soaked with $20 \mathrm{~mL}$ hexane for 24 hours in a sample bottle. After 24 hours, hexane was discarded and the cells were again soaked with $20 \mathrm{~mL}$ methanol for additional 24 hours. This process were repeated three times. Finally the cells were filtered through filter paper (Whatman no.1). The filtrate was evoperated with a rotary evoporator at $45^{\circ} \mathrm{C}$. The dry residue was redissolved in $1,25 \mathrm{~mL}$ methanol and filtered with milipore membrane $(0,45 \mu \mathrm{m}$, Whatman). The alkaloids content was determined by HPLC system (LC-10 ADVp Shimadzu). Cell extract of $20 \mu \mathrm{L}$ was injected into injector (Rheodyne, USA) connected to a reverse phase column with $5 \mu \mathrm{m}$ particle size and $250 \times 4,6 \mathrm{~mm}$ (Hypersil BDS column). The Ultra-violet detector (SPD-10 AVp Shimadzu UV-VIS) was used for the detection of the presence of 9-hydroxycanthin-6-one and 9-methoxycanthin-6-one in the extract. Mobile phase of the HPLC system comprised of acetonitride (Fisher Scientific) and 0,2\% acetic acid (Merck, Germany) in the ratio of $42: 58$. The flow rate was set to $2 \mathrm{~mL} / \mathrm{m}$. The elusion of alkaloids was detected at $280 \mathrm{~nm}$. The standards of 9-hydroxycanthin-6-one and 9-methoxycanthin-6-one were dissolved in methanol in a dilution series of $0,75,3,15,30,60,120$, and $250 \mathrm{mg} / \mathrm{L}$ to obtain the calibration curve for these two alkaloids. The area under the peak of the chromatogram for the standards was plotted against their respective concentration to obtain a regresion linear equation as below:

$$
\begin{aligned}
\mathrm{Y}= & \mathrm{mX}+\mathrm{c} \\
& \mathrm{Y}=\text { area under the peak of the chromatogram } \\
& \mathrm{X}=\text { concentration of the alkaloid }(\mathrm{mg} / \mathrm{L}) \\
& \mathrm{m} \text { and } \mathrm{c}=\text { constants }
\end{aligned}
$$

This regresion linear equation was used to obtained the concentration of alkaloids in the tested samples. The 9-hydroxycanthin-6-one and 9-methoxycanthin-6-one content in the sample could be obtained as:

$$
\%(w / w)=\frac{\text { alkaloid content in sample }(\mathrm{mg})}{\text { extract weight }(\mathrm{mg})} \times 100
$$

All experiments were carried out with 6 replicates. The data obtained for cell mass and alkaloids content were analysed separately using Two-Way analysis of Variance (ANOVA) followed by HSD Tukey Test at $p=0,05$.

\section{RESULTS}

Results revealed that certain elicitors affect the cell biomass and production of alkaloids from E. longifolia cells. MSBs medium supplemented with $100 \mathrm{mg} / \mathrm{L}$ chitosan induced significant increment in the cell biomass (FW 2,83 g; DW 0,26 g) as compared to the control (FW 1,47g; DW 0,14g) after 13 days of cell culture. The medium supplemented with $50 \mathrm{mg} / \mathrm{L}$ chitosan also showed increment in cell biomass (FW 1,70g; DW 0,17g). Lower amount of chitosan (10mg/L, 25mg/L) and high chitosan 
level $(150 \mathrm{mg} / \mathrm{L})$ present in the culture medium reduced the cell biomass. However, MSBc medium supplemented with $150 \mathrm{mg} / \mathrm{L}$ chitosan induced the highest production of 9-hydroxycanthin-6-one $(0,44 \%)$. The presence of chitosan in the culture medium did not induced the production of 9-methoxycanthin-6-one. In fact the absent of chitosan in the cell cultures had induced low production of 9-methoxycanthin-6-one $(0,08 \%)$ (Table 1$)$.
The MSBs medium supplemented with different concentration of $\mathrm{NaH}_{2} \mathrm{PO}_{4}$ also resulted in increment of cell biomass. The MSBs medium supplemented with $2 \mathrm{mg} / \mathrm{L}$ $\mathrm{NaH}_{2} \mathrm{PO}_{4}$ showed the highest increment in the cell biomass (FW 3,10g; DW 0,22g) as compared to the control (FW 0,66g; DW 0,07). Most of the $\mathrm{NaH}_{2} \mathrm{PO}_{4}$ treated cells showed increasing effect on the production of 9-hydroxycanthin-6-one except $5 \mathrm{mg} / \mathrm{L} \mathrm{NaH} \mathrm{PO}_{4}$. The addition of

TABLE 1

Effect of different elicitors supplemented into MSBs liquid medium on cell biomass and production of 9-hydroxycanthin-6-one and 9-methoxycxanthin-6-one from E. longifolia cells after 13 days of culture

\begin{tabular}{ccccc}
\hline $\begin{array}{c}\text { Concentration of Elicitor } \\
(\mathrm{mg} / \mathrm{L})\end{array}$ & $\begin{array}{c}\text { Fresh cell biomass } \\
(\mathrm{g})(\mathrm{n}=6)\end{array}$ & $\begin{array}{c}\text { Dry cell biomass } \\
(\mathrm{g})(\mathrm{n}=6)\end{array}$ & $\begin{array}{c}\text { \% w/w of } \\
\text { 9-hydroxycanthin-6-one }\end{array}$ & $\begin{array}{c}\text { \% w/w of } \\
\text { 9-methoxycanthin- 6-one }\end{array}$
\end{tabular}

\begin{tabular}{|c|c|c|c|c|}
\hline \multicolumn{5}{|l|}{ Chitosan } \\
\hline 0 & $1,47 \pm 0,18$ & $0,14 \pm 0,03$ & $0,08 \pm 0,05$ & $0,08 \pm 0,04$ \\
\hline 10 & $0,56 \pm 0,04$ & $0,06 \pm 0,01$ & $0,39 \pm 0,02$ & - \\
\hline 25 & $0,88 \pm 0,30$ & $0,07 \pm 0,02$ & $0,34 \pm 0,01$ & - \\
\hline 50 & $1,70 \pm 0,28$ & $0,17 \pm 0,03$ & $0,28 \pm 0,04$ & - \\
\hline 100 & $2,83 \pm 0,25$ & $0,26 \pm 0,03$ & $0,25 \pm 0,01$ & - \\
\hline 150 & $1,07 \pm 0,32$ & $0,07 \pm 0,01$ & $0,44 \pm 0,07$ & - \\
\hline \multicolumn{5}{|l|}{$\mathrm{NaH}_{2} \mathrm{PO}_{4}$} \\
\hline 0 & $0,66 \pm 0,03$ & $0,07 \pm 0,01$ & $0,08 \pm 0,02$ & $0,08 \pm 0,01$ \\
\hline 2 & $3,10 \pm 0,44$ & $0,22 \pm 0,05$ & $0,34 \pm 0,01$ & $0,94 \pm 0,00$ \\
\hline 5 & $1,20 \pm 0,35$ & $0,18 \pm 0,02$ & $0,08 \pm 0,01$ & $0,06 \pm 0,01$ \\
\hline 10 & $1,29 \pm 0,55$ & $0,11 \pm 0,02$ & $0,40 \pm 0,11$ & $0,16 \pm 0,04$ \\
\hline 15 & $1,56 \pm 0,48$ & $0,13 \pm 0,03$ & $0,39 \pm 0,01$ & $0,10 \pm 0,02$ \\
\hline 20 & $1,53 \pm 0,17$ & $0,13 \pm 0,02$ & $0,75 \pm 0,06$ & $0,41 \pm 0,02$ \\
\hline \multicolumn{5}{|l|}{$\mathrm{Na}_{2} \mathrm{CO}_{3}$} \\
\hline 0 & $0,50 \pm 0,01$ & $0,05 \pm 0,00$ & $0,11 \pm 0,02$ & $0,12 \pm 0,02$ \\
\hline 2 & $0,50 \pm 0,01$ & $0,05 \pm 0,01$ & $0,17 \pm 0,02$ & $0,22 \pm 0,02$ \\
\hline 4 & $0,46 \pm 0,04$ & $0,04 \pm 0,01$ & $0,31 \pm 0,02$ & $0,24 \pm 0,11$ \\
\hline 6 & $0,57 \pm 0,02$ & $0,05 \pm 0,00$ & $0,32 \pm 0,01$ & $0,27 \pm 0,06$ \\
\hline 8 & $0,60 \pm 0,01$ & $0,06 \pm 0,00$ & $0,23 \pm 0,00$ & $0,12 \pm 0,01$ \\
\hline 10 & $0,43 \pm 0,07$ & $0,04 \pm 0,00$ & $0,31 \pm 0,02$ & $0,24 \pm 0,07$ \\
\hline \multicolumn{5}{|c|}{ Polyvynylpirrolidone } \\
\hline 0 & $0,50 \pm 0,01$ & $0,05 \pm 0,00$ & $0,10 \pm 0,01$ & $0,11 \pm 0,03$ \\
\hline 10 & $0,44 \pm 0,01$ & $0,04 \pm 0,00$ & $0,28 \pm 0,01$ & $0,31 \pm 0,01$ \\
\hline 100 & $0,37 \pm 0,01$ & $0,03 \pm 0,00$ & $0,38 \pm 0,01$ & $0,22 \pm 0,01$ \\
\hline 500 & $0,43 \pm 0,02$ & $0,04 \pm 0,00$ & $0,55 \pm 0,04$ & $0,28 \pm 0,02$ \\
\hline 1000 & $0,48 \pm 0,01$ & $0,04 \pm 0,00$ & $0,26 \pm 0,04$ & $0,03 \pm 0,01$ \\
\hline 1500 & $0,43 \pm 0,01$ & $0,04 \pm 0,00$ & $0,50 \pm 0,00$ & $0,14 \pm 0,02$ \\
\hline
\end{tabular}


$20 \mathrm{mg} / \mathrm{L} \mathrm{NaH} \mathrm{PO}_{4}$ into the culture medium induced the highest production of 9-hydroxycanthin-6-one. While MSBs medium supplemented with $10 \mathrm{mg} / \mathrm{L} \mathrm{NaH}_{2} \mathrm{PO}_{4}$ induced the highest production of 9-methoxycanthin-6one in the cells (Table 1).

The addition of $\mathrm{Na}_{2} \mathrm{CO}_{3}$ into the cell cultures of E. longifolia showed marginal effect on cell biomass. The MSBs medium supplemented with $8 \mathrm{mg} / \mathrm{L}$ of $\mathrm{Na}_{2} \mathrm{CO}_{3}$ induced only slight increment in the cell biomass (FW 0,60g; DW $0,06 \mathrm{~g}$ ) as compared to the control (FW 0,50g; DW 0,05g). $\mathrm{MSBs}$ medium supplemented with $6 \mathrm{mg} / \mathrm{L} \mathrm{Na} 2 \mathrm{CO} 3$ increased production of 9-hydroxycanthin-6-one $(0,32 \%)$ and 9-methoxycanthin-6-one $(0,27 \%)$ in the cells as compared to the control (9-hydroxycanthin-6-one 0,11\%) and 9-methoxycanthin-6-one 0,12\%).

On the other hand, the cell culture medium of E. longifolia supplemented with polyvinylpyrrolidone caused reduction in cell biomass. However, the addition of $500 \mathrm{mg} / \mathrm{L}$ polyvinylpyrrolidone into the cell cultures induced the highest production of 9-hydroxycanthin-6-one $(0,55 \%)$ as compared to the other concentration. The presence of $10 \mathrm{mg} / \mathrm{L}$ polyvinylpyrrolidone in the cell cultures induced approximately equal amount of 9-hydroxycanthin-6one $(0,28 \pm 0,01 \%)$ and 9-methoxycanthin-6-one (0,31 \pm $0,01 \%$ ) and high cell biomass (Table 1 ).

The presence of 9-hydroxycanthin-6-one and 9-methoxycanthin-6-one were determined by comparing the retention time betwen the alkaloid standard and the samples. The retention time for 9-hyroxycanthin-6-one was 2,092 minute and for 9-methoxycanthin-6-one was 4,317 minute (Fig. 1 and 2).

Observation under light microscope showed that the cell walls of E. longifolia were broken after soaking in methanol for 72 hours. Even the cell lysis, there was only about $20 \%$ of the extract obtained after the evaporation process (data not shown). This indicated that there was

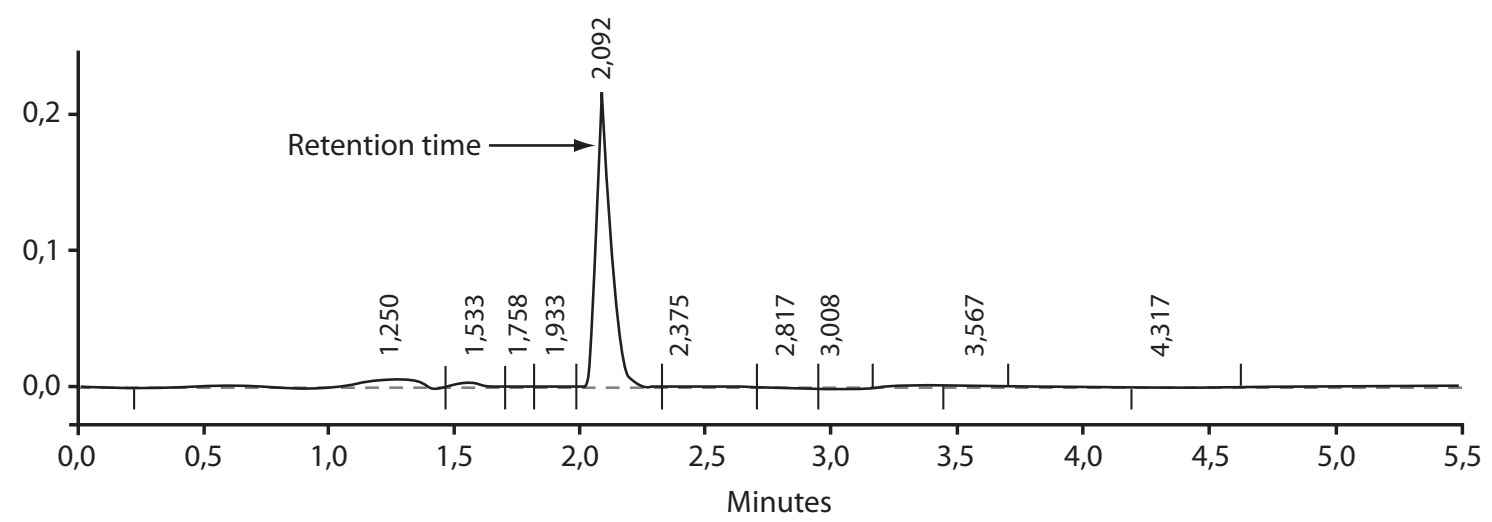

FIG. 1. Chromatogram of 9-hydroxycanthin-6-one standard with retention time of 2,092 min.

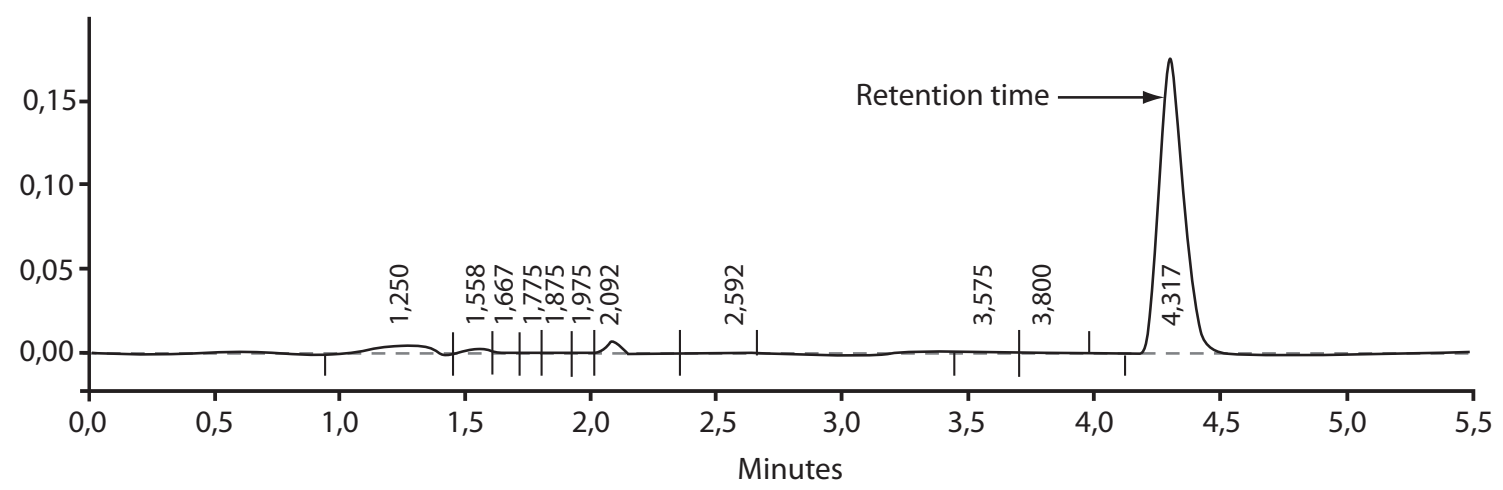

FIG. 2. Chromatogram of 9-methoxycanthin-6-one standard with retention time of 4,317 $\mathrm{min}$ 
still a lot of alkaloids retained in the cells. Therefore, the cells can be soaked for a longer period in methanol solvent to release more alkaloids.

\section{DISCUSSION}

Generally, most of the pharmaceutically important secondary metabolites are isolated from wild or cultivated plants because their chemical synthesis is not economically feasible. The production of useful and valuable secondary metabolites via cell cultures system could be a better alternative. Plant cell culture system is a potential source of valuable secondary metabolites which can be used as food additives, nutraceuticals and pharmaceuticals purposes (Zhong 2001). Elicitation is one of the most effective ways to promote secondary metabolites production in plant cell cultures (Zhang et al. 2000). Elicitors have been successfully used for the production of secondary metabolites in cell cultures of different species such as Thalictrum rugosum (Brodelius et al. 1989), Tagetes patula (Buitelaar et al. 1992), Catharanthus roseus (Vázquez-Flota et al. 1994), Taxus sp. (Ciddi et al. 1995) and many others. Production of secondary metabolites in plants is mostly occurred due to stress created by abiotic and biotic factors. Elicitors may be biotic or abiotic, which possess the ability to induce physiological changes in the living organism such as plant cells (Zhao et al. 2005).

MSBs medium supplemented with 50 and $100 \mathrm{mg} / \mathrm{L}$ chitosan, significantly increased the cell biomass of Eurycoma longifolia. The MSBs medium supplimented with lower amount $(10 \mathrm{mg} / \mathrm{L}, 25 \mathrm{mg} / \mathrm{L})$ and higher ammount of chitosan $(150 \mathrm{mg} / \mathrm{L})$ reduced the cell biomass. However, the higher concentration of chitosan $(150 \mathrm{mg} / \mathrm{L})$ showed the highest production of 9-hydroxycanthin-6-one but it did not affects the production of 9-methoxycanthin-6-one. From the biosynthesis pathway, 9-methoxycanthin-6-one was derived from 9-hydroxycanthin-6-one. The biosynthesis pathway might be blocked by chitosan which probably induced some enzymatic reaction or production of some inhibitors that inhibited the production of 9-methoxycanthin-6-one. These findings were in tune with Palazón et al. (2003) who reported the similar effect of chitosan in Panax ginseng.

MSBs medium supplemented with different concentration of $\mathrm{NaH}_{2} \mathrm{PO}_{4}$ showed the increment of cell biomass and also increased the production of 9-hydroxycanthin-6-one except $5 \mathrm{mg} / \mathrm{L} \mathrm{NaH}_{2} \mathrm{PO}_{4}$. The similar results were reported by Toivonen et al. (1989) in Catharanthus roseus, where the addition of $\mathrm{NaH}_{2} \mathrm{PO}_{4}$ was effective in increasing the cell biomass and alkaloid production. The active mechanisms of elicitors are considered to be special and complex. Since little information is available on the biosynthetic pathways of most secondary metabolites in plants, the effect of elicitation on the plant cell culture cannot be predicted easily. The effect of elicitors also depends on many factors such as elicitor concentration, the growth stage of the culture at the time of elicitation and the contact time of elicitation. Addition of polyvinylpyrrolidone in MSBs medium caused the reduction in cell biomass. However, the addition of $500 \mathrm{mg} / \mathrm{L}$ polyvinylpyrrolidone induced the highest production of 9-hydroxycanthin-6-one $(0,55 \%)$. These results are in agrrement with Zhao et al. (2000), who reported that polyvinylpyrrolidone inhibited the cell growth but it increase the ajmalicine production in Catharanthus roseus.

This study indicated that different elicitors had different effect on cell biomass and alkaloids production from $E$. longifolia cells. The addition of $100 \mathrm{mg} / \mathrm{L}$ chitosan or $2 \mathrm{mg} / \mathrm{L} \mathrm{NaH} \mathrm{PO}_{4}$ into the cell cultures caused 5,7 and 6,2 folds increased in cell biomass while the addition of $\mathrm{Na}_{2} \mathrm{CO}_{3}$ and polyvinylpyrrolidone did not accelerate cell growth. Culture media supplemented with higher concentration of Chitosan $(150 \mathrm{mg} / \mathrm{L})$ or $\mathrm{NaH}_{2} \mathrm{PO}_{4}(20 \mathrm{mg} / \mathrm{L})$ induced significantly higher alkaloid production.

\section{REFERENCES}

Bedir, E., J. Abou-Gazar, N. Ngwendson \& I.A. Khan . 2003. Eurycomaoside: A Novel Compound from the Roots of Eurycoma longifolia. Chemical Pharmaceutical Bulletin 51:1301-1303.

Brodelius, P., MA. Collinge, C. Funk, K. Gügler \& I. Marques. 1989. Studies on alkaloid formation in plant cell cultures after treatment with a yeast elicitor. In: W.G.W. Kurz (ed.), Primary and secondary metabolism of plant cell cultures Springer-Verlag, Berlin.

Buitelaar, R.M., M.T. Cesario \& J. Tramper. 1992. Elicitation of thiophene production by hairy roots of Tagetes patula. Enzyme Microbial Technology 14: 2-7.

Chan, K., C.Y. Choo \& N. Abdullah. 2005. Semisynthetic 15-O-acyland 1,15-di-O-acyleurycomanones from Eurycoma longifolia as potential antimalarials. Planta Medica 71: 967-969.

Ciddi, V., V. Srinivasan \& M.L. Shuler. 1995. Elicitation of Taxus sp. cell culture for production of taxol. Biotechnology Letters 17:1343-1346.

Goh, S.H., C.H. Chuah, J.S.L. Mok \& E. Soepadmo. 1995. Malaysian Medicinal Plants for the Treatment of Cardiovascular Diseases, Pelanduk Publication Sdn. Bhd., Selangor, Malaysia.

Hout, S., A. Chea, S. Bun, R. Elias, M. Gasquet, P. Timon-David, G. Balansard \& N. Azas . 2006. Screening of selected indigenous plants of Cambodia for antiplasmodial ativity. Journal Ethnopharmacology 107:12-18.

Jiwajinda, S., V. Santisopasri, A. Murakami, M. Kawanaka, H. Kawanaka, M. Gasquet, R. Eilas, G. Balansard \& H. Ohigashi. 
2002. In vitro anti-tumor promoting anti-parasitic activities of the quassinoids from Eurycoma longifolia, a medicinal plant in Southeast Asia. Journal Ethnopharmacology 82: 55-58.

Kuo, P., L. Shi, A. Damu, C. Su, C.Huang, C. Ke, J. Wu, A. Lin, K. Bastow, K. Lee \& T. Wu. 2003. Cytotoxic and antimalarial betacarboline alkaloids from the roots of Eurycoma longifolia. Journal Natural Products 66: 1324-1327.

Lufthi, A. 2004. Pengoptimuman kultur ampaian sel eurycoma longifolia jack untuk penghasilan biojisim dan alkaloid. Ph.D. Thesis. Universiti Sains Malaysia. Penang, Malaysia.

Morita, H., E. Kishi, K. Takeya, H. Itokawa \& O. Tanaka. 1990. New quassinoids from the roots Eurycoma longifolia. Chemistry Letters 5: 749-752.

Nurhanan, M.Y., L. Azimahtol, A. Mohd \& M. Mohd. 2005. Cytotoxic effects of the root extracts of Eurycoma longifolia Jack. Phytotherapy Research 19: 994-996.

Osman, A., B. Jordan, P. Lessard, N. Muhammad, M. Haron, N. Riffin, A. Sinskey, C. Rha \& D. Housman. 2003. Genetic diversity of Eurycoma longifolia inferred from single nucleotide polymorphisms. Plant Physiolology 131: 1294-1301.

Palazón, J., R. Cusido, M. Bonfil, A. Mallol, E. Moyamo, C. Marales \& M. Pinol. 2003. Elicitation of different Panax ginseng transformed root phenotypes for an improvement ginsenoside production. Plant Physiology Biochemistry 41: 1019-1025.

Perry, L. \& J. Metzger. 1980. Medicinal plants of East and Southeast Asia: Attributed properties and uses. M.I.T., Cambridge, United Kingdom

Tee, T.T. \& H. Azimzhtol. 2005. Induction of apoptosis by Eurycoma longifolia Jack extracts. Anticancer Research 25: 2205-2213.
Toivonen, L., M. Ojala \& V. Kauppinen. 1991. Studies on the optimization of growth and indole alkaloids production by hairy roots cultures of Catharanthus roseus. Biotechnolology Bioengineering 37: 673-680.

Ueda, J.Y., Y. Tezuka, A. Banskota, Q. Le-Tran, Q. Tran, Y. Harimaya, I. Saiki \& S. Kadota. 2002. Antiproliferative activity of Vietnamese medicinal plants. Biological \& Pharmaceutical Bulletin 25: 735-760.

Vázquez-Flota, F., O. Moreno-Valenzuela, M. Miranda-Ham, J. Coello-Coello \& V. Loyola-Vargas.1994. Catharanthine and ajmalicine synthesis in Catharanthus roseus hairy root cultures. Medium optimization and elicitation. Plant Cell, Tissue Organ Culture. 38: 273-279.

Zhang, C., X. Mei, L. Yu \& X. Liu. 2000. Initiation, growth and taxol production of Taxus chinensis embryo-derived cell line. Journal Huazhong University of Science Technology 28: 60-63.

Zhao, J., T. Lawrence, C. Davis \& R. Verpoorte. 2005. Elicitor signal transduction leading to production of plant secondary metabolites. Biotechnology Advances. 23: 283-333

Zhao, J., Z. Wei-Hua, H. Qiu \& G. Ying-Qing. 2000. Improvement of indole alkaloid production in Catharanthus roseus cell. cultures by osmotic shock. Biotechnology Letters 22: 1227-1231.

Zhari, I., I. Norhayati \& L. Jaafar. 1999. Malaysian Herbal Monograph. National Pharmaceutical Control Bureau, Ministry of Agriculture, Malaysia.

Zhong, J.J. 2001. Biochemical engineering of the production of plant-specific secondary metabolites by cell suspension cultures. Advances in Biochemical Engineering/Biotechnology $72: 26$. 